\title{
Acrylamide: Increased Concentrations in Homemade Food and First Evidence of Its Variable Absorption from Food, Variable Metabolism and Placental and Breast Milk Transfer in Humans
}

\author{
Fritz Sörgela Rainer Weissenbacherb Martina Kinzig-Schippers ${ }^{a}$ \\ Annette Hofmann ${ }^{b}$ Michael Illauer ${ }^{a}$ Andreas Skotta \\ Cornelia Landersdorfer ${ }^{a}$ \\ aInstitute for Biomedical and Pharmaceutical Research, Nürnberg-Heroldsberg, b Department of Gynecology, \\ University of Munich, Munich, Germany
}

\section{Key Words \\ Acrylamide · Food • Variable metabolism • Breast milk • Placenta Absorption}

\begin{abstract}
We have developed a liquid chromatography/mass spectrometry (LC-MS/MS) assay to determine acrylamide in various body fluids. The assay also allows the reliable quantitation of acrylamide in food. In a total of 11 healthy male and female subjects, we were able to show that acrylamide from food given to humans is in fact absorbed from the gut. The half-lives determined in two male subjects were 2.2 and $7 \mathrm{~h}$. Acrylamide was found in human breast milk and penetrated the human placenta $(n=3)$. The variability of acrylamide concentrations found in this investigation is most likely caused by variable intersubject bioavailability and metabolism. This may be an important indication that the assessment of
\end{abstract}

This work was supported in part by a grant from META Productions, Berlin, Germany. Thanks to Wilhelm Ritter, Claudia Brause, Inga Kling, and Ulrich Meyer at META Productions for helpful suggestions.

\section{KARGER}

Fax +41613061234

E-Mail karger@karger.ch

www. karger.com
(C) 2002 S. Karger AG, Basel

0009-3157/02/0486-0267\$18.50/0

Accessible online at:

www. karger.com/che the risk from acrylamide for the individual may be very difficult without knowing the concentrations of acrylamide in the body. This should be considered in the design of any risk assessment study or post hoc analysis of earlier studies. At this time, we suggest that pregnant women and breast-feeding mothers avoid acrylamide-containing food.

Copyright $\odot 2002$ S. Karger AG, Basel

\section{Introduction}

Previously, the risks involved in acrylamide exposure were thought to be primarily related to high-volume use of the monomer, the popular use of polyacrylamide products in effluent and water treatment as a flocculant or exposure of workers to acrylamide [1-4]. Also, its increasing use as a grout raised concerns [1,2]. Acrylamide has been identified as being carcinogenic, neurotoxic, genotoxic and a category 3 reprotoxicant [5-13] in animals. Neurotoxic effects have also been shown in humans, including the nonfatal outcome of a deliberate ingestion of as much as $18 \mathrm{~g}$ of acrylamide crystals [14]. The patient in this report suffered from severe neurotoxicity but survived. Practi-

\footnotetext{
Fritz Sörgel, $\mathrm{PhD}$

IBMP - Institute for Biomedical and Pharmaceutical Research

Paul-Ehrlich-Strasse 19

D-90562 Nürnberg-Heroldsberg (Germany)

Tel. +49 911518 290, Fax +49911518 2920, E-Mail ibmp@osn.de
} 
cally all of the information on acrylamide toxicity in humans originates from inhalation and dermal uptake, with occasional reports of deliberate uptake or accidental uptake, e.g. of acrylamide in drinking water [15].

Recently, however, acrylamide has been identified to occur in food [16-19]. That has led to worldwide efforts to understand the mechanisms of its formation in food and assess the risk to consumers. It was shown soon after that observation that reducing sugars and amino acids, predominantly asparagine in starch-rich food and heating beyond $140^{\circ} \mathrm{C}$, lead to significant but also variable acrylamide formation [20,21].

Authors of several studies suggested that acrylamide toxicity may be related to the formation of a hemoglobin adduct in animals [22-26] as well as in humans [27-30]. This adduct is considered a surrogate of toxicity since if acrylamide can react with hemoglobin it should also be able to react with other large molecules such as important and functional proteins and DNA. Similarly, glycidamide, the metabolite of acrylamide, may react with hemoglobin. Although these reactions may be interrelated, there has been no convincing evidence up to now that hemoglobin adduct measurements may help to assess the cancer risk of acrylamide in humans [31].

Acrylamide has been shown to be converted to glycidamide, the epoxide of acrylamide, by cytochrome P450 2E1 [32]. The involvement of cytochrome P450 enzymes raises the question of polymorphic metabolism of the chemical, possibly leading to variable toxic effects. However, at this time there is little evidence that acrylamide is in fact governed by a polymorphic metabolism [33]. Other metabolic steps include formation of a glutathione conjugate. Most if not all information on the fate of acrylamide in the body stems from in vitro studies and studies in animals where it was given by oral, intravenous, intraperitoneal and dermal routes [34-36]. In humans, no data have become available on the direct measurement of acrylamide in blood, plasma, tissue and urine, except for the case of intoxication mentioned above [14]. The only other information on the uptake of acrylamide by humans in a greater number of individuals comes from measurement of hemoglobin adducts [27-30].

The limitation of using the measurement of hemoglobin adduct data for assessing the fate of acrylamide in the body is its site of formation. It seems that acrylamide penetrates red blood cells readily, and formation of the adduct occurs in a cellular compartment. This method seems suitable to measure the chronic uptake of acrylamide into the blood circulation. However, it cannot be used to measure uptake of acrylamide in tissues of interest for potential toxic effects of acrylamide. Finally, measurement of these adducts is of no use to measure the toxicokinetics after ingestion of a 'single dose' of acrylamide by a human individual. Hemoglobin adduct measurement is therefore only of very limited value and will not contribute to the assessment of toxic effects in the tissues, not to mention the fact that hemoglobin is not a site of acrylamide toxicity.

Very recently, a report by Mucci et al. [37] released information from a population-based case-control study that was planned to assess the relationship between heterocyclic amines in fried food and cancer. The authors claimed to have found no evidence that acrylamide in amounts typically ingested in Sweden has any measurable effect on the risk of three major types of cancer. That study has major shortcomings that have been and certainly will be discussed by the scientific community in the very near future. Two major shortcomings of such studies and in particular the conclusions from such a study that are related to the work described here are presented.

Firstly, the relationship between 'intake' of acrylamide and cancer risk was based entirely on data on the food itself. Since no study has ever been done where it has in fact been shown that acrylamide is absorbed from the gut, this kind of data may only provide vague indications. The bioavailability of acrylamide from different foods and in different humans can be so different that the groups of 'acrylamide intake' formed in that study may not at all reflect the quantitative intake precisely.

Secondly, the authors make a most misleading and scientifically unsound case that acrylamide is "effectively detoxified'. In subsequent media interviews with the first author, this argument was further propounded [18]. There is no pharmacological basis whatsoever for this unscientific statement. Of greater concern, those arguments were used to further support the most questionable conclusion of the nonexistence of a cancer risk.

In any case, it is apparent that there is a lack of toxicokinetic data in humans and that it is most important that such data are obtained. We report the results of a pilot study of acrylamide in humans. Regular food was administered to a total of 13 humans. Acrylamide was analyzed in urine and breast milk. Additionally, three fresh placentas from three mothers were perfused with acrylamide and the fetal concentration was assessed. This first investigation of the fate of acrylamide in the body became possible after successful development of the first bioanalytical methodology to analyze acrylamide in these matrices by LC-MS/MS (tandem mass spectrometry). 


\section{Subjects and Methods}

Nine healthy male volunteers ( $18-52$ years old) ate commercially available food in amounts of up to $500 \mathrm{~g}$ of potato chips or crisp bread. Urine samples were collected before and after food ingestion. Two apparently healthy mothers ate about $100 \mathrm{~g}$ of self-prepared potato chips (mother No. 1, age 33 years) and $100 \mathrm{~g}$ of commercially available potato chips (mother No. 2, age 24 years). All subjects were apparently healthy. The amount of acrylamide was estimated to be about $1 \mathrm{mg}$ in mother 1 and $800 \mu \mathrm{g}$ in the other. The placentas used for this investigation came from documented healthy mothers who remained anonymous to the investigators.

The food listed in table 1 was prepared in a home kitchen and a typical household setting from commercially available potato or carbohydrate, oil and fat sources. Preparation of food was done in a regular household oven or microwave oven.

To evaluate the extent of placental transfer of acrylamide, an in vitro perfused human postpartum placenta model was used. Three human placentas were obtained following caesarean section. The construction for the dual simultaneous perfusion of an isolated cotyledon consisted of two separate pump systems for the maternal and fetal circuits, respectively, the perfusion chamber and thermostats to control the temperature of the perfusion chamber and the perfusates. The composition of the perfusates for the maternal and fetal sides of the placenta was identical, i.e. TC medium 199, bovine albumin, dextran and sodium bicarbonate in distilled water. However, acrylamide was added to the maternal perfusate to achieve a concentration close to $1 \mu \mathrm{g} / \mathrm{ml}$. Before the start of the perfusion, the solutions were heated to $37^{\circ} \mathrm{C}$, gassed with carbogen $(95 \%$ oxygen, $5 \%$ carbon dioxide) and adjusted to a $\mathrm{pH}$ of 7.4 in order to establish approximately physiological conditions. During perfusion, the perfusates and perfusion chamber were maintained at $37^{\circ} \mathrm{C}$. Perfusates were not recirculated. To establish the fetal circuit, cannulae were inserted into both the fetal artery and fetal vein of a peripheral cotyledon. The perfusion chamber contained a port for the influx of the fetal arterial perfusate and a sampling port for the fetal venous perfusate. The maternal arterial perfusate reached the intervillous space of the cotyledon through five catheters simulating the maternal endometrial arterioles. The sampling port for the discharged maternal venous perfusate was located at the bottom of the perfusion chamber. Maternal and fetal perfused samples were obtained from the separate sampling ports after 1, 3, 5, 9, 15, 25 and 30 min during perfusion and stored for analysis.

Measurement of acrylamide in urine, breast milk and placenta perfusion medium by liquid chromatography/mass spectrometry (LC-MS/MS) was performed as follows. Urine samples were thawed and vigorously mixed. To $6 \mathrm{ml}$ of urine sample $150 \mu \mathrm{l}$ of internal standard solution and buffer were added. Acrylamide was extracted by liquid/liquid extraction and the organic solvent subsequently evaporated to $200 \mu \mathrm{l}$ under a stream of $\mathrm{N}_{2}$ at $35^{\circ} \mathrm{C}$.

Placental perfusate samples were thawed and vigorously mixed. To $0.25 \mathrm{ml}$ of placental perfusate sample $50 \mu \mathrm{l}$ of internal standard solution and buffer were added. Acrylamide was extracted by liquid/ liquid extraction and the organic solvent subsequently evaporated to $200 \mu \mathrm{l}$ under a stream of $\mathrm{N}_{2}$ at $35^{\circ} \mathrm{C}$.

Breast milk samples were thawed and vigorously mixed. To $2.5 \mathrm{ml}$ of breast milk sample $50 \mu \mathrm{l}$ of internal standard solution and buffer were added. Acrylamide was extracted by liquid/liquid extraction and the organic solvent subsequently evaporated to $200 \mu \mathrm{l}$ under a stream of $\mathrm{N}_{2}$ at $35^{\circ} \mathrm{C}$.

Placental and Breast Milk Transfer of Acrylamide
Table 1. Acrylamide content of food

a Potato chips and French fries listed according to parameters studied for influence on acrylamide formation

\begin{tabular}{|c|c|c|c|c|}
\hline Sample & Size, $\mathrm{mm}$ & $\begin{array}{l}\text { Cooking } \\
\text { temperature } \\
{ }^{\circ} \mathrm{C}\end{array}$ & $\begin{array}{l}\text { Cooking } \\
\text { time } \\
\text { min }\end{array}$ & $\begin{array}{l}\text { Acrylamide } \\
\text { concentration } \\
\mu \mathrm{g} / \mathrm{kg}\end{array}$ \\
\hline \multirow[t]{8}{*}{ Potato chips } & 3 & 180 & 2 & $2,557.9$ \\
\hline & 3 & 140 & 2 & 36.3 \\
\hline & 3 & 180 & 4 & $7,678.3$ \\
\hline & 3 & 140 & 4 & 53.3 \\
\hline & 1 & 180 & 1 & 121.1 \\
\hline & 1 & 140 & 2 & 20.0 \\
\hline & 1 & 180 & 3 & $9,670.2$ \\
\hline & 1 & 140 & 4 & 35.3 \\
\hline \multirow[t]{16}{*}{ French fries } & 5 & 180 & 2 & $1,716.9$ \\
\hline & 5 & 160 & 2 & 53.8 \\
\hline & 5 & 140 & 2 & 11.0 \\
\hline & 5 & 180 & 4 & $2,687.0$ \\
\hline & 5 & 160 & 4 & $1,049.5$ \\
\hline & 5 & 140 & 4 & 77.0 \\
\hline & 10 & 180 & 2 & 674.2 \\
\hline & 10 & 160 & 2 & $<8$ \\
\hline & 10 & 140 & 2 & $<8$ \\
\hline & 10 & 180 & 4 & $1,084.3$ \\
\hline & 10 & 160 & 4 & 87.3 \\
\hline & 10 & 140 & 4 & 10.0 \\
\hline & 13 & 180 & 4 & 476.2 \\
\hline & 13 & 140 & 2 & $<8$ \\
\hline & 13 & 180 & 6 & 880.0 \\
\hline & 13 & 140 & 4 & $<8$ \\
\hline
\end{tabular}

b Other foods

\begin{tabular}{|c|c|c|c|c|}
\hline Sample & Description & $\begin{array}{l}\text { Cooking } \\
\text { method }\end{array}$ & $\begin{array}{l}\text { Cooking } \\
\text { time } \\
\text { min }\end{array}$ & $\begin{array}{l}\text { Acrylamide } \\
\text { concentration } \\
\mu \mathrm{g} / \mathrm{kg}\end{array}$ \\
\hline Walnuts & - & roasted & - & $<8$ \\
\hline Pine seeds & - & roasted & - & 16.4 \\
\hline Candied chestnuts & - & baked & - & 8.3 \\
\hline Crème caramel & - & boiled & - & $<8$ \\
\hline Whiskey & - & - & - & $<8$ \\
\hline Liver of beef & - & baked & - & $<8$ \\
\hline Breaded fish & - & baked & - & $<8$ \\
\hline Goose skin & - & oven & - & $<8$ \\
\hline Goose meat & - & oven & - & $<8$ \\
\hline \multirow[t]{3}{*}{ Gingerbread } & lightly baked & $200^{\circ} \mathrm{C}$ & - & 12.1 \\
\hline & dark baked & $200^{\circ} \mathrm{C}$ & - & 113.0 \\
\hline & - & - & - & 180.7 \\
\hline Gingerbread balls & - & - & - & 639.5 \\
\hline Spiced cookies & - & - & - & 143.6 \\
\hline \multirow[t]{5}{*}{ Popcorn } & - & $\mathrm{mw}, 800 \mathrm{~W}$ & 1 & 29.7 \\
\hline & - & $\mathrm{mw}, 600 \mathrm{~W}$ & 2 & 50.0 \\
\hline & - & $\mathrm{mw}, 800 \mathrm{~W}$ & 2 & 132.8 \\
\hline & - & $\mathrm{mw}, 600 \mathrm{~W}$ & 3 & 250.3 \\
\hline & - & $\mathrm{mw}, 600 \mathrm{~W}$ & 4 & 307.1 \\
\hline \multirow[t]{2}{*}{ Croquettes } & - & $180^{\circ} \mathrm{C}$ & 2 & 354.7 \\
\hline & - & $180^{\circ} \mathrm{C}$ & 4 & 453.4 \\
\hline \multirow[t]{2}{*}{ Hash browns } & - & $180^{\circ} \mathrm{C}$ & 2 & 446.1 \\
\hline & - & $180^{\circ} \mathrm{C}$ & 4 & 751.7 \\
\hline Fried potatoes & - & - & - & 543.1 \\
\hline Croutons & - & baked & - & 27.8 \\
\hline Bread crust & - & - & - & 370.6 \\
\hline Toast & - & toasted & - & 54.1 \\
\hline
\end{tabular}

$\mathrm{mw}=$ Microwave.

Chemotherapy 2002;48:267-274 
$20 \mu \mathrm{l}$ of each sample were analyzed. Chromatographic separation was performed using a reversed-phase column eluted with an isocratic solvent system consisting of water, acetic acid and an organic modifier and monitored by LC-MS/MS (acrylamide: $\mathrm{m} / \mathrm{z}$ (mass to charge ratio) $72 \rightarrow \mathrm{m} / \mathrm{z} 55$; internal standard: $\mathrm{m} / \mathrm{z} 75 \rightarrow \mathrm{m} / \mathrm{z} 58)$. Under these conditions, acrylamide and the internal standard eluted after approximately $1.9 \mathrm{~min}$ for placental perfusate and breast milk and $2.4 \mathrm{~min}$ for urine. The data acquisition was done by RAD (version 2.6, PE Sciex, Thornhill, Ont., Canada) and the data processing by MacQuan (version 1.6, Perkin Elmer, Toronto, Canada, 19911998).

Urine, placental perfusate or breast milk samples were measured against a urine, placental perfusate or breast milk calibration row, respectively. Calibration standards were prepared by adding the appropriate volumes of standard solution of acrylamide to acrylamide-free human urine, perfusate or breast milk. Concentrations were obtained down to a concentration of $1 \mathrm{ng} / \mathrm{ml}$ for urine, $2 \mathrm{ng} / \mathrm{ml}$ for placenta perfusate and $5 \mathrm{ng} / \mathrm{ml}$ for breast milk. Similar procedures were used for food.

There was no interference observed for acrylamide or the internal standard. Weighted linear regression $\left(1 /\right.$ peak area ratio $\left.^{2}\right)$ was performed for calibration. Linearity of the calibration could be proven between 1 and $100 \mathrm{ng} / \mathrm{ml}$ for urine, 2 and $1,000 \mathrm{ng} / \mathrm{ml}$ for placental perfusate and 5 and $20 \mathrm{ng} / \mathrm{ml}$ for breast milk. Quantification levels were identical with the lowest calibration levels.

Interassay precision of the SQCs (spiked quality controls) of acrylamide were $1.1 \%(1,000 \mathrm{ng} / \mathrm{ml}), 3.3 \%(500 \mathrm{ng} / \mathrm{ml}), 3.1 \%(50 \mathrm{ng} /$ $\mathrm{ml})$ and $6.1 \%(5 \mathrm{ng} / \mathrm{ml})$, and the accuracy of the standards ranged from 98.6 to $101.4 \%$.

\section{Results and Discussion}

This study revealed many new insights into the acrylamide problem. Furthermore, it showed for the first time the successful use of an LC-MS/MS assay to measure unchanged acrylamide in the human body. Our newly developed assay is suitable for analyzing acrylamide down to concentrations as low as $1 \mathrm{ng} / \mathrm{ml}$ in urine, $5 \mathrm{ng} / \mathrm{ml}$ in breast milk and $2 \mathrm{ng} / \mathrm{ml}$ in placental perfusate. The range of linearity was up to $1,000 \mathrm{ng} / \mathrm{ml}$. The assay proved most reliable in many analyses. There was no interference of any endogenous material, although acrylamide has a very small molecular weight. Intra- and interday variation were excellent. Experience with other subsequent samples proved the high reliability of the assay. The assay was also used in a modified form to analyze acrylamide in homemade food. The LC-MS/MS technology also proved most suitable during these analyses.

The findings in homemade food were most surprising (table 1). To prepare food at home is by no means to avoid acrylamide formation. On the contrary, it is most likely that at home, when the temperature and duration of cooking are arbitrary and where French fries or potato chips are prepared to yield a brownish color, extremely high
Table 2. Urinary concentrations of acrylamide and amount excreted within $8 \mathrm{~h}$

\begin{tabular}{llll}
\hline Subject No. & $\begin{array}{l}\text { Calculated } \\
\text { concentration } \\
\text { ng/ml }\end{array}$ & $\begin{array}{l}\text { Amount of } \\
\text { urine } \\
\mathrm{g}\end{array}$ & $\begin{array}{l}\text { Excretion } \\
\mu \mathrm{g}\end{array}$ \\
\hline $\begin{array}{l}\text { Before food } \\
1\end{array}$ & $\mathrm{BQL}$ & 142.3 & - \\
2 & $\mathrm{BQL}$ & 350.0 & - \\
3 & $\mathrm{BQL}$ & 152.8 & - \\
4 & 2.04 & 531.2 & 1.084 \\
5 & $\mathrm{BQL}$ & 618.4 & - \\
6 & $0.659^{*}$ & 677.3 & $* *$ \\
7 & $\mathrm{BQL}$ & 780.3 & $* *$ \\
8 & $0.712 *$ & 474.7 & - \\
9 & $\mathrm{BQL}$ & 330.2 & 0.338 \\
\hline After food & & & - \\
1 & 3.56 & 135.4 & 0.8462 \\
2 & $\mathrm{BQL}$ & 875.8 & 0.971 \\
3 & 5.27 & 160.6 & 5.702 \\
4 & 1.97 & 493.8 & 0.996 \\
5 & 6.31 & 903.3 & 3.662 \\
6 & 2.63 & 378.9 & 1.030 \\
7 & 3.62 & $1,011.6$ & 5.047 \\
8 & 4.05 & 254.3 & \\
9 & 5.54 & 911 & \\
\hline
\end{tabular}

Dashes indicate no acrylamide excretion. $\mathrm{BQL}=$ Below quantification level.

* Below quantification level, but clearly measurable peaks in chromatogram; ** no calculation performed because BQL.

acrylamide contents of these foods are possible. To our knowledge, the highest-ever reported content of $9,670 \mu \mathrm{g} /$ $\mathrm{kg}$ acrylamide was found in homemade potato chips of $1 \mathrm{~mm}$ after $3 \mathrm{~min}$ of heating at our institution. The diameter of the food and temperature and duration of cooking were the key parameters for any type of food prepared. Also, when corn was prepared to yield popcorn at $600 \mathrm{~W}$, the duration of microwave treatment was important. It is also of interest that German Christmas cookies, spiced biscuits and gingerbread balls contained high amounts of acrylamide. Any type of animal meat and skin contained no or negligible amounts of acrylamide. Our data support previous findings by others that acrylamide is formed in foods that contain carbohydrates and asparagine and are heated towards $180^{\circ} \mathrm{C}$. Others have demonstrated that the water content is an important factor. Thin slices for potato chips lead to quick evaporation of water and make ideal conditions for acrylamide formation. 
Table 3. Concentrations of acrylamide in fetal perfusate

\begin{tabular}{lcccc}
\hline $\begin{array}{l}\text { Sampling } \\
\text { time } \\
\text { min }\end{array}$ & \multicolumn{2}{l}{ Concentration of acrylamide, $\mathrm{ng} / \mathrm{ml}$} & $\begin{array}{l}\text { Average } \\
\text { concentration } \\
\mathrm{ng} / \mathrm{ml}\end{array}$ \\
\cline { 2 - 4 } & experiment 1 & experiment 2 & experiment 3 & - \\
\hline 1 & BQL & BQL & BQL & - \\
5 & 11.86 & 38.00 & 31.91 & 27.26 \\
5 & 182.2 & 100.2 & 70.74 & 117.7 \\
9 & 382.8 & 105.1 & 73.07 & 187.0 \\
15 & 323.0 & 118.1 & 72.97 & 171.3 \\
25 & 339.5 & 114.0 & 70.23 & 174.6 \\
30 & 300.6 & 107.6 & 63.61 & 157.3 \\
\hline
\end{tabular}

The dash indicates that no calculation was possible. $\mathrm{BQL}=$ Below quantification level $(2.00 \mathrm{ng} / \mathrm{ml})$.

Our study also shows that a prevention strategy may be used by heating to clearly less than $180^{\circ} \mathrm{C}$ and making prepared products very thick. This can most likely be explained by reversing the effect of the factors of heat, water content and diameter. However, food prepared in this way is less likely to be acceptable in taste. Yet, our investigations demonstrate that acrylamide prevention programs and appropriate parameter control at home and at industrial manufacturing sites are possible.

We tested another carbohydrate as a reaction partner of asparagine, i.e. glycogen from liver of beef, and found no appreciable acrylamide formation. This suggests that not just any macromolecular carbohydrate is able to react with asparagine. Glycogen is obviously not a source of acrylamide formation.

Of the 9 subjects participating in the study (table 2), acrylamide could be detected in 8 . Subject 2 ate a very small amount of potato chips (less than $100 \mathrm{~g}$ ). The amounts of acrylamide excreted in the urine were very small in the other 8 volunteers. This does not, however, suggest that the bioavailability from food ingestion was small. In humans, probably more than $90 \%$ of acrylamide is metabolized and only a small fraction is excreted unchanged. Variability in urinary excretion of acrylamide between subjects was very high, which may be caused by high variability in oral bioavailability and/or hepatic metabolism. In 2 subjects, we were able to determine a halflife of acrylamide of $2.2 \mathrm{~h}$ in one case and $7 \mathrm{~h}$ in the other (fig. 1). The half-life in subject 2 was hampered due to some type of second peak phenomenon that is observed in pharmacology for certain drugs. The data confirm that the half-life of acrylamide in humans is short in some subjects and intermediate in others. Clearly, the data demonstrate
Table 4. Concentrations of acrylamide in maternal perfusate

\begin{tabular}{lllll}
\hline $\begin{array}{l}\text { Sampling } \\
\text { time } \\
\text { min }\end{array}$ & \begin{tabular}{l} 
Concentration of acrylamide, ng/ml \\
\cline { 2 - 3 }
\end{tabular} & experiment 1 & experiment 2 & $\begin{array}{l}\text { Average } \\
\text { concentration } \\
\mathrm{ng} / \mathrm{ml}\end{array}$ \\
\hline 1 & BQL & BQL & BQL & - \\
3 & 416.5 & 484.9 & 550.1 & 483.8 \\
5 & 573.7 & 931.9 & 583.6 & 696.4 \\
9 & 772.2 & 1,070 & 723.9 & 855.4 \\
15 & 930.7 & 1,066 & 695.2 & 897.3 \\
25 & 809.5 & 1,049 & 696.5 & 851.7 \\
30 & 887.1 & 867.6 & 710.9 & 821.8 \\
\hline
\end{tabular}

The dash indicates that no calculation was possible. $\mathrm{BQL}=$ Below quantification level $(2.00 \mathrm{ng} / \mathrm{ml})$.
Table 5. Transfer of acrylamide across the placenta (\%*)

\begin{tabular}{llrll}
\hline $\begin{array}{l}\text { Sampling } \\
\begin{array}{l}\text { time } \\
\text { min }\end{array}\end{array}$ & \multicolumn{2}{l}{ Penetration, \% } & Average \\
\cline { 2 - 4 } & experiment 1 & experiment 2 & experiment 3 & \\
\hline 1 & - & - & - & - \\
3 & 2.8 & 7.8 & 5.8 & 5.5 \\
5 & 31.8 & 10.8 & 12.1 & 18.2 \\
9 & 49.6 & 9.8 & 10.1 & 23.2 \\
15 & 34.7 & 11.1 & 10.5 & 18.8 \\
25 & 41.9 & 10.9 & 10.1 & 21.0 \\
30 & 33.9 & 12.4 & 8.9 & 18.4 \\
\hline
\end{tabular}

Dashes indicate that no calculation was possible. *\% of plasma concentrations.

Table 6. Concentrations of acrylamide in breast milk

\begin{tabular}{lll}
\hline $\begin{array}{l}\text { Sampling } \\
\text { time } \\
\text { h }\end{array}$ & \multicolumn{2}{l}{ Concentration of acrylamide in breast milk, ng/ml } \\
\cline { 2 - 3 } & mother 1 & mother 2 \\
\hline Pre-dose & BQL & BQL \\
1 & - & BQL \\
3 & 10.6 & - \\
4 & 18.8 & 4.86 \\
8 & - & 3.17
\end{tabular}

$\mathrm{BQL}=$ Below quantification level; $-=$ no sample. 
Fig. 1. Acrylamide excretion in two healthy subjects. a Excretion of acrylamide during the collection period. b Cumulative excretion. The half-life of acrylamide was $7.0 \mathrm{~h}$ in subject 1 and $2.2 \mathrm{~h}$ in subject $2 . \diamond=$ Subject $1 ; \boldsymbol{\square}=$ subject 2 .
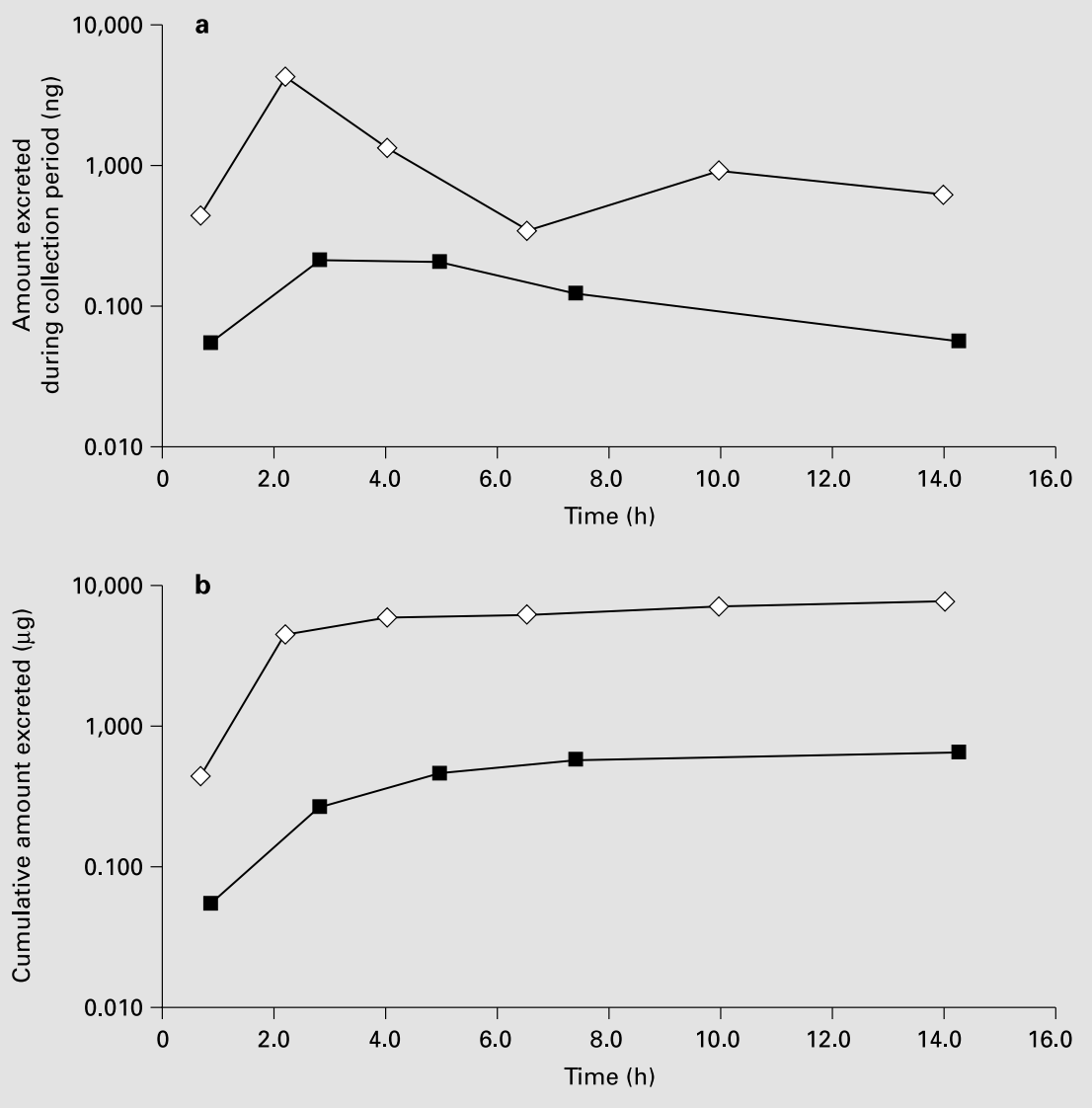

that acrylamide is not an ultra-short half-life agent in humans. Unlike the statement of Mucci et al. [37] that there is fast clearance of acrylamide from the body, our findings do not support the idea of quick elimination or those authors' conclusions that acrylamide has no carcinogenic effects because of fast excretion. The most important result of our pilot study is that acrylamide is in fact absorbed from food ingested by humans. This is, to our knowledge, the first proof of the bioavailability of acrylamide from food in humans. The high variability of acrylamide levels in urine may be a first hint of the difficulties that large population studies may face when attempting to assess the risk of cancer. In addition, our data support the criticism of the study of Mucci et al. [37] regarding their use of general data on food content but no individual human bioavailability data to assess the cancer risk in humans. The issue may turn out to be a most complex one involving individual and possibly genetic factors that determine the metabolic fate of acrylamide. The variability of the fate of acrylamide in humans during this study also became apparent from the fact that 3 of our 9 subjects had predose levels of acrylamide (table 2). Thus, these subjects may be slow eliminators of acrylamide.

Of immediate consequence for the public are our findings on the penetration of acrylamide into breast milk (tables 5 and 6). Predose levels in these mothers were not measurable, since they did not consume any possibly contaminated food for $10 \mathrm{~h}$ prior to the dose. Based on a daily consumption of $500 \mathrm{ml}$ of breast milk, the intake can be as high as $10 \mu \mathrm{g}$ of acrylamide for a baby if the mother eats highly acrylamide-loaded food like one of our mothers. Even in the other mother, who ate smaller amounts of potato chips, an intake of about $2 \mu \mathrm{g}$ may be calculated. In those cases, the dose for a $3-\mathrm{kg}$ baby would be 3.3 and $0.66 \mu \mathrm{g} / \mathrm{kg}$ acrylamide, respectively. Estimations of the cancer risk assume 10 in 1,000 cancer cases per $1 \mu \mathrm{g}$ per day. For chemically related agents like vinyl chloride, a higher sensitivity of young individuals has been found in animals [38]. The neurotoxicity of acrylamide is also higher in the young compared to older animals [39]. Exposing 
young humans to these amounts of acrylamide during breast-feeding seems to be unacceptable. The significant placental transfer of acrylamide (tables 3 and 4 ) is even more concerning. The unborn may be exposed to unacceptably high levels of acrylamide. In this population, the neurotoxicity may present an even more immediate and direct problem. It is well known that fetuses and newborns do not have a fully established blood-brain and probably blood-CSF barrier [40]. Mothers consuming high amounts of acrylamide-containing food pose a risk to their children by significant prenatal transfer of acrylamide and hence the risk of neurotoxicity. This continues postnatally until breast-feeding is stopped.

In summary, our first-ever data on the toxicokinetics of acrylamide in humans may have a significant impact on the consumption of food containing acrylamide. First, industrially prepared food may be superior to homemade food when the latter is prepared without following the rules derived from this and other investigations. The findings in humans call for studies defining the factors that cause the variabilities in acrylamide levels and hence adverse effects of acrylamide. Until a possibly high individual risk is known, consumption of acrylamide-containing food should be minimized. In pregnant and postpartum breast-feeding mothers, acrylamide-containing food must be omitted. In the general population, the high variability of the bioavailability of acrylamide and its metabolism to the more toxic glycidamide may be the greatest obstacle to assessing the risk of cancer or neurotoxicity following acrylamide ingestion. More importantly, the individual risks caused by variability of acrylamide levels in the body - as was very clearly shown in the present study - may be even more challenging to research on acrylamide.

\section{References}

1 U.S. Department of Health and Human Services, Public Health Service, Center for Disease Control, National Institute for Occupational Safety Health: Registry of Toxic Effects of Chemical Substances (RTECS). 2001. National Library of Medicine's current MEDLARS file, p 82/8010.

2 World Health Organization: Acrylamide. Environmental Health Criteria 49. Geneva, World Health Organization, 1985.

3 Smith EA, Oehme FW: Acrylamide and polyacrylamide: A review of production, use, environmental fate and neurotoxicity. Rev Environ Health 1991;9:215-228.

4 Marsh GM, Lucas LJ, Youk AO, Schall LC: Mortality patterns among workers exposed to acrylamide: 1994 follow up. Occup Environ Med 1999;56:181-190.

5 Bull RJ, Robinson M, Laurie RD, Stoner GD, Greisiger E, Meier JR, Stober J: Carcinogenic effects of acrylamide in Sencar and A/J mice. Cancer Res 1984;44:107-111.

6 Sobel W, Bond GG, Parsons TW, Brenner FE: Acrylamide cohort mortality study. $\mathrm{Br} \mathrm{J}$ Ind Med 1986;43:785-788.

7 Costa LG, Deng H, Gregotti C, Manzo L, Faustman EM, Bergmark E, Calleman CJ: Comparative studies on the neuro- and reproductive toxicity of acrylamide and its epoxide metabolite glycidamide in the rat. Neurotoxicology 1992;13:219-224.

8 Tsuda H, Shimizu CS, Taketomi MK, Hasegawa MM, Hamada A, Kawata KM, Inui N: Acrylamide; induction of DNA damage, chromosomal aberrations and cell transformation without gene mutations. Mutagenesis 1993;8: 23-29.
9 Tyl RW, Marr MC, Myers CB, Ross WP, Friedman MA: Relationship between acrylamide reproductive and neurotoxicity in male rats. Reprod Toxicol 2000;14:147-157.

10 Walden R, Squibb RE, Schiller CM: Effects of prenatal and lactational exposure to acrylamide on the development of intestinal enzymes in the rat. Toxicol Appl Pharmacol 1981;58: 363-369.

11 Zenick H, Hope E, Smith MK: Reproductive toxicity associated with acrylamide treatment in male and female rats. $\mathrm{J}$ Toxicol Environ Health 1986;17:457-472.

12 Cihak R, Vontorkova M: Cytogenetic effects of acrylamide in the bone marrow of mice. Mutat Res 1988;209:91-94.

13 Kankaanpaa J, Elovaara E, Hemminki K, Vainio H: Embryotoxicity of acrolein, acrylonitrile and acrylamide in developing chick embryos. Toxicol Lett 1979;4:93-96.

14 Donovan J, Pearson T: Ingestion of acrylamide with severe encephalopathy, neurotoxicity and hepatotoxicity. Vet Hum Toxicol 1987;29: 462.

15 Johnson KA, Gorzinski SJ, Bodner KM, Campbell RA, Wolf $\mathrm{CH}$, Friedman MA, Mast RW: Chronic toxicity and oncogenicity study on acrylamide incorporated in the drinking water of Fischer 344 rats. Toxicol Appl Pharmacol 1986;85:154-168.

16 Tareke E, Rydberg P, Karlsson P, Eriksson S, Tornqvist M: Acrylamide: A cooking carcinogen? Chem Res Toxicol 2000;13:517-522.

17 World Health Organization: Additional research on acrylamide in food essential, scientists declare. Joint WHO/FAO Press Release/ 51. Geneva, WHO, 2002 (http://www.who.int/ inf/en/pr-2002-51.html).
18 Reaney P: Study doubts acrylamide in food causes cancer. London, Reuters Health, 2003 (http://www.nlm.nih.gov/medlineplus/news/ fullstory 11451.html).

19 Swedish National Food Administration: Information about acrylamide in food. Uppsala, Swedish National Food Administration, 2002 (http://192.71.90.8/engakrylanalysresultat. htm).

20 Mottram DS, Wedzicha BL, Dodson AT: Acrylamide is formed in the Maillard reaction. Nature 2002;419:448-449.

21 Stadler RH, Blank I, Varga N, Robert F, Hau J, Guy PA, Robert MC, Riediker S: Acrylamide from Maillard reaction products. Nature 2002; 419:449-450.

22 Paulsson B, Grawe J, Tornqvist M: Hemoglobin adducts and micronucleus frequencies in mouse and rat after acrylamide or N-methylolacrylamide treatment. Mutat Res 2002;516: 101-111.

23 Barber DS, Hunt JR, Ehrich MF, Lehning EJ, LoPachin RM: Metabolism, toxicokinetics and hemoglobin adduct formation in rats following subacute and subchronic acrylamide dosing. Neurotoxicology 2001;22:341-353.

24 Calleman CJ, Bergmark E, Costa LG: Acrylamide is metabolized to glycidamide in the rat: Evidence from hemoglobin adduct formulation. Chem Res Toxicol 1990;3:406-412.

25 Perez HL, Cheong HK, Yang JS, OstermanGolkar S: Simultaneous analysis of hemoglobin adducts of acrylamide and glycidamide by gas chromatography-mass spectrometry. Anal Biochem 1999;274:59-68. 
26 Bergmark E, Calleman CJ, Costa LG: Formation of hemoglobin adducts of acrylamide and its epoxide metabolite glycidamide in the rat. Toxicol Appl Pharmacol 1991;111:352-363.

27 Bergmark E, Calleman CJ, He F, Costa LG: Determination of hemoglobin adducts in humans occupationally exposed to acrylamide. Toxicol Appl Pharmacol 1993;120:45-54.

28 Hagmar L, Tornqvist M, Nordander C, Rosen I, Bruze M, Kautiainen A, Magnusson AL, Malmberg B, Aprea P, Granath F, Axmon A: Health effects of occupational exposure to acrylamide using hemoglobin adducts as biomarkers of internal dose. Scand J Work Environ Health 2001;27:219-226.

29 Bergmark E: Hemoglobin adducts of acrylamide and acrylonitrile in laboratory workers, smokers and nonsmokers. Chem Res Toxicol 1997;10:78-84.

30 Calleman CJ, Wu Y, He F, Tian G, Bergmark E, Zhang S, Deng H, Wang Y, Crofton KM, Fennell T, Costa L: Relationships between biomarkers of exposure and neurological effects in a group of workers exposed to acrylamide. Toxicol Appl Pharmacol 1994;126:361-371.
31 Decaprio PA: Biomarkers: Coming of age for environmental health and risk assessment. Environ Sci Technol 1997;31:1837-1848.

32 Sumner SC, Fennell TR, Moore TA, Chanas B, Gonzalez F, Ghanayem BI: Role of cytochrome P450 2E1 in the metabolism of acrylamide and acrylonitrile in mice. Chem Res Toxicol 1999; 12:1110-1116.

33 Tanaka E, Terada M, Misawa S: Cytochrome P450 2E1: Its clinical and toxicological role. J Clin Pharm Ther 2000;25:165-175.

34 Ikeda GJ, Miller E, Sapienza PP, Michel TC, King MT, Turner VA, Blumenthal H, Jackson WE 3rd, Levin S: Distribution of ${ }^{14} \mathrm{C}$-labelled acrylamide and betaine in foetuses of rats, rabbits, beagle dogs and miniature pigs. Food Chem Toxicol 1983;21:49-58.

35 Ikeda GJ, Miller E, Sapienza PP, Michel TC, King MT, Sager AO: Maternal-foetal distribution studies in late pregnancy. II. Distribution of $\left[1-{ }^{14} \mathrm{C}\right]$ acrylamide in tissues of beagle dogs and miniature pigs. Food Chem Toxicol 1985; 23:757-761.
36 Ikeda GJ, Miller E, Sapienza PP, Michel TC, Inskeep PB: Comparative tissue distribution and excretion of $\left[1-{ }^{14} \mathrm{C}\right]$ acrylamide in beagle dogs and miniature pigs. Food Chem Toxicol 1987;25:871-875.

37 Mucci LA, Dickman PW, Steineck G, Adami $\mathrm{HO}$, Augustsson K: Dietary acrylamide and cancer of the large bowel, kidney, and bladder: Absence of an association in a populationbased study in Sweden. Br J Cancer 2003;88: 84-89.

38 Laib RJ, Bolt HM, Cartier R, Bartsch H: Increased alkylation of liver DNA and cell turnover in young versus old rats exposed to vinyl chloride correlates with cancer susceptibility. Toxicol Lett 1989;45:231-239.

39 Ko MH, Chen WP, Lin-Shiau SY, Hsieh ST: Age-dependent acrylamide neurotoxicity in mice: Morphology, physiology, and function. Exp Neurol 1999;158:37-46.

40 Rodier PM: Developing brain as a target of toxicity. Environ Health Perspect 1995;103(suppl 6):73-76. 